\title{
Identifikasi Komponen Kimia Pada Umbi Bentul (Colocasia esculenta (L.) Schott) Sebagai Pangan Fungsional
}

\section{Chemical Component Identification of (Colocasia esculenta (L.) Schoot) as Functional Food}

\author{
Ambar Fidyasari ${ }^{*}{ }^{*}$, Rizky Mayang Sari ${ }^{2}$, Sentot Joko Raharjo ${ }^{3}$
}

\begin{abstract}
ABSTRAK
Latar belakang: Umbi-umbian saat ini mulai banyak dieksplorasi untuk mengetahui komponen penting yang terdapat dalam umbi tersebut. Umbi bentul salah satu umbi yang pemanfaatan belum dieksplorasi secara maksimal.

Tujuan: dari penelitian ini adalah untuk mengetahui komponen kimia yang terdapat dalam bentul. Metode: Tahapan penelitian ini meliputi pertama, tahap determinasi untuk mengetahui kebenaran tanaman yang akan digunakan. Kedua, tahap persiapan serta pelaksanaan meliputi proses pembuatan tepung bentul, pengujian mutu kimia atau proksimat tepung meliputi karbohidrat, protein, lemak, kadar abu, kadar air dan serat. Ketiga, ekstraksi tepung untuk mendapatkan senyawa yang diduga PLA dan analisanya dengan menggunakan HPLC.

Hasil: Berdasarkan penelitian menunjukkan hasil komponen kimia protein $3,45 \%$, lemak $0,31 \%$, air $6,07 \%$, abu $2,14 \%$, karbohidrat $88,03 \%$, dan serat $2,87 \%$. Rendemen hasil ekstraksi tepung yaitu $2,9 \%$ dan $9,0 \%$.

Kesimpulan : Analisa dari ekstrak tepung terbukti mengandung polisakarida dengan adanya DP dan DP5 memiliki total $72,356 \%$ dan $87,98 \%$ namun belum diketahui jenis gula penyusunnya.
\end{abstract}

Kata kunci : umbi bentul, komponen kimia, pangan fungsional, senyawa bioaktif

\begin{abstract}
Background: Nowadays tubers are mostly explored to determinetheir essential components. Colocasia esculenta (I.) Schottis one of tubers that its use has not been maximally explored.

Objective: This research aims to identify the chemical components onColocasia esculenta (I.) Schott. Methods: The research stages include, first, the determination for finding out the right plant; second, the preparation and implementation (including theflour preparation andits proximate testing asthe carbohydrate, protein, fat, carbon, moisture and fiber testing); third, the flour extraction for obtaining the PLA and its PLA analysis using HPLC.

Results: The result shows the chemical components of protein is $3.45 \%$, fat is $0.31 \%$, moisture is $6.07 \%$, carbon is $2.14 \%$, carbohydrate is $88.03 \%$, and fiber is $2.87 \%$. The yield extraction results are $2.9 \%$ and $9.0 \%$.

Conclusion: The flour extraction analysis displays polysaccharide proven by the presence of DP and DP5 of $72.356 \%$ and $87.98 \%$. However, its sugar molecule composition has not been identified yet.
\end{abstract}

Keywords: Colocasia esculenta (I.) Schott, chemical component, functional food, bioactive component 


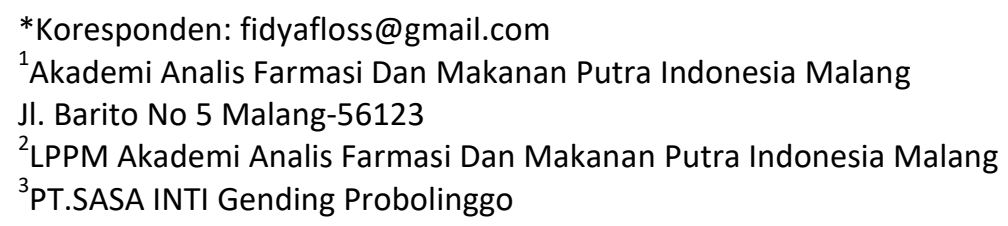

\section{PENDAHULUAN}

Bentul merupakan salah satu jenis umbi yang telah banyak dikenal oleh masyarakat. Masyarakat mengenal bentul dengan nama keladi. Bentul tersebar hampir diseluruh Indonesia dan produksi bentul semakin mengalami kenaikan. Menurut Nurbaya, 2013 bahwa pada tahun 2011 melalui pelaksanaan kegiatan area pangan alternatif, jumlah produktivitas bentul dari beberapa daerah adalah 661 kwintal/hektar. Umbi bentul memiliki produktifitas yang melimpah, namun pemanfaatan dari bentul belum dieksplorasi secara maksimal. Pemanfaatan bentul dalam masyarakat pedesaan hanya sebatas digoreng atau dikukus. Masyarakat belum banyak mengetahui tentang keunggulan dari bentul yang memiliki senyawa bioaktif yang dapat dimanfaatkan sebagai pangan fungsional.

Saat ini, umbi yang telah dieksplor senyawa bioaktifnya adalah kelompok Dioscorea. Harijono., 2012 menyatakan bahwa hal yang menarik dari kelompok dioscorea adalah selain komponen yang berperan dalam bahan pangan adalah mengandung senyawa bioaktif atau senyawa fungsional. Hasil penelitian yang telah ada dari keluarga Dioscorea yang lain Dioscorea alata, Dioscorea batatas, Dioscorea bulbifera, Dioscorea opposita menunjukkan bahwa keluarga Dioscorea mengandung senyawa bioaktif berupa dioscorin, diosgeni dan polisakarida larut air ${ }^{1}$.

Polisakarida Larut Air (PLA) merupakan serat pangan larut air yang didefinisikan sebagai komponen dalam tanaman yang tidak terdegradasi secara enzimatis menjadi sub unit yang dapat diserap dilambung dan usus halus. PLA biasa juga disebut hidrokoloid, dewasa ini PLA banyak sekali dimanfaatkan dalam industri makanan guna mencapai kualitas yang diharapkan, dalam hal viskositas, stabilitas, tekstur, dan penampilan ${ }^{2}$. Menurut Herlina, (2014) PLA merupakan serat pangan larut air bersifat hidrokoloid. Bahan yang bersifat hidrokoloid banyak digunakan oleh industri pangan sebagai bahan tambahan makanan (food aditive) yang berfungsi sebagai bahan pengikat air (water binding), pengental (thickener), suspending agent, stabilizer, meningkatkan "mouth feel" dari berbagai macambahan pangan, serta mempunyai potensi bioaktif sebagai penurun kadar kolesterol darah (hipokolesterolemik) dan memperbaiki profil lipid (hipolipidemik) ${ }^{3}$.

Umbi-umbian yang saat ini banyak jenisnya belum dieksplorasi. Selain eksplorasi dari umbi-umbian tersebut, perlu juga untuk diidentifikasi kandungan komponen kimia dan bioaktifnya untuk mengetahui komponen kimia dan bioaktif dari setiap umbi. Komponen kimia yang telah diketahui dapat digunakan sebagai acuan pembuatan pangan fungsional dengan memanfaatkan umbi sebagai bahan dasar. Pangan fungsional adalah pangan yang mengandung komponen aktif yang dapat memberikan manfaat bagi kesehatan, diluar manfaat yang diberikan oleh zat-zat gizi yang terkandung di dalamnya. Melihat data diatas mengenai keluarga dari Dioscorea beserta senyawa aktif didalamnya maka perlunya mengeksplorasi lebih dalam keluarga dari Colocasia. Sedangkan untuk bentul belum ada penelitian mengenai senyawa bioaktif yang ada didalamnya Perlu penelitian lebih lanjut untuk mengetahui senyawa bioaktif yang terdapat dalam bentul dan kadar yang dimiliki. 


\section{METODE}

\section{Bahan dan Alat}

Bahan utama yang digunakan dalam penelitian ini adalah umbi bentul putih(Colocasia Esculenta L Schott). Bahan pembantu pembuatan tepung bentul adalah garam dapur. Bahan dalam proses ekstraksi adalah tawas dan etanol.

Alat yang digunakan dalam penelitian ini meliputi glasswear, magnetic stirer, kompor gas, pengaduk, oven listrik (Memmert U.30), vortex (LW Scientific), desikator, beaker glass, bola hisap, corong kaca, tabung reaksi, rak tabung reaksi, kertas saring halus, alumunium foil, cawan alumunium, plastik, labu ukur, piet ukur, dan pipet tetes., sentrifuge, dan HPLC.

Penelitian ini dilakukan dengan metode eksperimen dengan tujuan untuk mengidentifikasi komponen kimia dan bioaktif pada umbi bentul (Colocasia Esculenta L Schott). Tahap penelitian meliputi tahap persiapan, tahap pelaksanaan dan tahap akhir. Tahap awal yang perlu dilakukan adalah determinasi tanaman bentul untuk mengetahui kebenaran tanaman. Tahap pelaksanaan meliputi proses pembuatan tepung bentul dan pengujian mutu kimia atau proksimat. Tahap akhir adalah proses ekstraksi umbi bentul untuk mendapatkan senyawa polisakarida larut air (PLA) yang kemudian dianalisa menggunakan instrumen atau alat HPLC.

\section{Pelaksanaan Penelitian \\ Determinasi}

Determinasi ini di perlukan untuk mengetahui kebenaran dari tanaman yang digunakan yaitu umbi bentul (Colocasia Esculenta $L$ Schott). Proses determinasi dilakukan di laboratorium Farmakognosi Materia Medika Batu.

\section{Pembuatan Tepung Ubi Bentul}

Bentul dikupas, kemudian dicuci bersih untuk menghilangkan zat-zat pengotor. Lalu bentul dipotong tipis 1-2 $\mathrm{mm}$ untuk mempermudah pengeringan. Selanjutnya bentul direndam dengan menggunakan air garam untuk menghilangkan kalsium oksalat. Kemudian dikeringkan dengan menggunakan oven dengan suhu $60^{\circ} \mathrm{C}$ selama jam. Selanjutnya dihaluskan dengan mesin penggiling dan diletakkan dalam kemasan tertutup.

\section{Proses Ekstraksi}

Tepung bentul ditimbang sebanyak $10 \mathrm{~g}$ kemudian ditambahkan dengan aquadest panas suhu $70^{\circ} \mathrm{C}$ kemudian dilakukan proses pengadukan dengan diatur suhu $70^{\circ} \mathrm{C}$. Kemudian dilakukan proses sentrifuge dengan kecepatan 3000 rpm selama 10 menit. Hasil dari sentrifuge diambil supernatan yang akan dipresipitasi dengan etanol dengan perbandingan (1:1) selama 24 jam. Selanjutnya dilakukan proses penyaringan dan dikeringkan dengan oven suhu $500 \mathrm{C}$ selama 18 jam.

\section{Penentuan Komponen Kimia}

Analisa komponen kimia serat kasar mengacu SNI 01-2891-1992, analisa protein mengacu AOAC (1970), analisa lemak metode Soxhlet mengacu pada AOAC (2005), analisa kadar abu mengacu pada SNI 01-2891-1992, dan analisa kadar air menggunakan metode gravimetri AOAC (1970).

\section{Analisa Ekstrak}

Ekstrak ditambahkan dengan $50 \mathrm{~mL}$ aquadest kemudian dipanaskan dengan suhu $85^{\circ} \mathrm{C}$ selama 15 menit. Selanjutnya disentrifuge $20.000 \mathrm{rpm}$ dan setelah itu disaring dengan kertas saring $0,45 \mu$. Hasil dari penyaringan kemudian dilanjutkan injeksi ke HPLC.

\section{HASIL DAN PEMBAHASAN}

\section{Determinasi}

Bagian tanaman bentul yang digunakan pada penelitian ini adalah umbi bentul yang diperoleh dari pasar besar Malang. Determinasi tanaman bentul dilakukan di laboratorium Farmakognosi Materia Medika Batu. Tujuan determinasi adalah untuk 
mengidentifikasi kecocokan atau kebenaran tanaman yang digunakan. Hasil determinasi menunjukkan bahwa tanaman bentul yang digunakan adalah tanaman bentul (Colocasia esculenta (L.)Schott).

\section{Rendemen Tepung Bentul (Colocasia Esculenta (L.) Schott)}

Rendemen adalah berat bahan setelah proses dibandingkan dengan berat bahan sebelum proses. Rendemen tepung umbi bentul adalah $24 \%$. Terdapat beberapa faktor yang mempengaruhi dari hasil rendemen. Menurut Saputri (2013) tingkat rendemen umbi sangat dipengaruhi oleh interaksi antara umur panen dan klon pada umbi. Rendemen tepung juga dapat dipengaruhi oleh kadar air karena setiap bahan memiliki kadar air yang optimal untuk mencapai rendemen tepung optimal. Selain itu, kenaikan suhu alat yang digunakan untuk penepungan karena gesekan dan pemakaian berlebih juga dapat menurunkan rendemen ${ }^{4}$.

\section{Hasil Analisa Proksimat Tepung Umbi Bentul}

Pengujian proksimat pada tepug bentul dimaksudkan untuk mengetahui kandungan makronutrien yang meliputi protein, lemak, air, abu, karbohidrat. Pengujian kimia pada tepung umbi bentul ini bertujuan untuk mengetahui komponen kimia nya dibandingkan dengan umbi lain yang telah dilakukan penelitian. Dimana hasil kimia dari tepung umbi bentul dapat dilihat pada tabel 1 .

Hasil data diatas menunjukkan dalam tepung bentul mengandung kandungan protein sebanyak $3,45 \%$, lemak $0,31 \%$, air
6,07\%, abu $2,14 \%$, karbohidrat $88,03 \%$, dan serat kasar $2,87 \%$.

\section{Kadar Protein}

Protein merupakan makronutrien dan komponen yang penting dalam tubuh. Fungsi utama protein adalah sebagai zat pembangun tubuh. Peranan protein cukup penting sebagai kebutuhan untuk setiap harinya. Dari hasil analisa kadar protein dalam tepung umbi bentul didapatkan hasil sebesar $3,45 \%$. Hasil kadar protein hampir sama dengan penelitian Estiasih, (2012) dimana kadar protein tepung Dioscorea alata dari berbagai daerah yang dianalisa sebesar $3,03-9,05 \%{ }^{5}$. Kadar protein tepung bentul pada penelitian ini lebih rendah daripada tepung gandum, yaitu sekitar $10 \%{ }^{6}$, tetapi lebih tinggi daripada tepung ubi jalar $( \pm 3 \%)^{7}$. Kadar protein dalam tepung diperlukan untuk aplikasinya, apabila tepung berkadar protein tinggi maka dalam aplikasinya pada proses pembuatan makanan pada roti, mie atau makanan lain tidak perlu menambahkan substitusi lagi.

\section{Kadar Lemak}

Lemak memiliki 2 jenis yaitu lemak jenuh dan lemak tak jenuh. Bagi penderita kolesterol tinggi lemak tak jenuh sangat dibutuhkan sebagai asupan karena tidak akan membahayakan bagi kesehatan. Kadar lemak yang terukur dari umbi bentul sebesar 0,31\%. Nilai ini lebih rendah jika dibandingkan dengan umbi lain seperti ubi kelapa kuning sebesar $0,57 \%$. Kadar lemak pada tepung bentul ini

Tabel 1. Parameter hasil pengujian tepung umbi bentul

\begin{tabular}{ccccccc}
\hline Parameter & Bentul & $\begin{array}{c}\text { Ubi kelapa } \\
\text { ungu* }\end{array}$ & $\begin{array}{c}\text { Ubi kelapa } \\
\text { kuning* }\end{array}$ & Ganyong** & Suweg** & Gembili** \\
\hline Protein & 3,45 & 8,33 & 6,00 & 0,73 & 5,22 & 6,11 \\
Lemak & 0,31 & 0,49 & 0,40 & 1,22 & 1,64 & 0,89 \\
Air & 6,07 & 4,40 & 5,86 & 6,69 & 9,4 & 6,44 \\
Abu & 2,14 & 3,62 & 3,93 & 2,89 & 3,81 & 2,87 \\
Karbohidrat & 88,03 & & & & & \\
Serat & 2,87 & & & & & \\
\hline
\end{tabular}

Sumber: *Saputri, 2013; **Richana dan Sunarti 2004 
memiliki kadar lemak lebih rendah dibandingkan dengan beberapa umbi yang lain, sehingga dapat dijadikan sebagai pangan fungsional.

\section{Kadar Air}

Kadar air mempengaruhi efektifitas pengemasan dan juga daya simpan bahan. Semakin tinggi kadar air maka semakin mudah suatu bahan tersebut akan rusak. Kadar air yang diperoleh dari hasil penelitian terhadap umbi bentul sebesar $6,07 \%$ hasil ini hampir menyerupai atau sama dengan kadar air pada umbi ganyong dan gembili. Tetapi lebih besar dari ubi kelapa ungu dan ubi kelapa kuning. Hasil kadar air yang berbeda dipengaruhi oleh varietas, umur tanam, unsur hara tanah dan iklim. Standar tepung menurut SNI (37512009) kadar air tepung maksimal adalah $14 \%{ }^{9}$. Sehingga pada penelitian ini kadar air tepung umbi bentul sebesar 6,07\% masih memenuhi standar. Kadar air yang didapat pada suatu produk akan mempengaruhi lama simpan atau daya tahannya.

\section{Kadar Abu}

Kadar abu mempengaruhi kenampakan tepung yang menjadikan tepung berwarna kurang menarik dengan warna lebih gelap. Abu adalah zat anorganik sisa hasil pembakaran suatu bahan organic. Kadar abu ada hubungannya dengan mineral suatu bahan. Nilai dari kadar abu dalam tepung tersebut berasal dari mineral yang terdapat dalam umbi segar dan bergantung pula tanah tempat tumbuh. Kadar abu yang diperoleh dari hasil penelitian terhadap umbi bentul menunjukkan hasil 2,14\%, hasil ini lebih kecil jika dibandingkan dengan ubi kelapa dan umbi suweg. Sedangkan standar kadar abu sesuai SNI 3751:2009 pada komoditi tepung antara 2,5- 7,0 \% sehingga kadar abu pada umbi bentul ini masih memenuhi syarat yang ditentukan.

\section{Kadar Karbohidrat}

Karbohidrat merupakan salah satu komponen yang penting bagi asupan makanan yang berfungsi sebagai energi. Konsumsi karbohidrat ini akan diolah oleh tubuh menjadi energi untuk melakukan kegiatan sehari-hari. Semakin tinggi karbohidrat dalam suatu bahan maka akan menggenyangkan lebih lama. Dari hasil perhitungan didapatkan bahwa kadar karbohidrat yang terdapat pada umbi bentul sebesar 88,03\%. Karbohidrat terdiri dari fraksi pati dan serat kasar. Kedua fraksi ini merupakan bagian penting yang dapat dipergunakan sebagai komponen bioaktif dari umbi bentul. Menurut penelitian Nurcahya (2013) bentul sebagai salah satu jenis umbi-umbian yang dapat digunakan sebagai pengganti nasi bagi penderita diabetes, karena bentul mengandung serat dan protein yang cukup tinggi yang bisa menurunkan kadar glukosa darah. sehingga umbi bentul ini sangat baik digunakan pada orang obesitas ${ }^{10}$.

\section{Kadar Serat}

Serat larut adalah bagian dari bahan pangan yang tidak dapat dihidrolisis oleh enzim-enzim didalam pencernaan. Terdiri atas serat pangan larut dan tidak larut air. Serat pangan larut dapat larut dalam air hangat, seperti gum dan pektin. Serat tidak larut air merupakan serat pangan yang tidak larut dalam air panas seperti selulosa dan lignin. Serat yang terkandung pada tepung umbi bentul sebesar $2,87 \%$. Nilai kadar serat ini lebih kecil dari penelitian Saputri, (2013) dimana serat pada tepung ubi kelapa kuning dan ungu memiliki kadar sebesar $26 \%$ terdiri atas $24 \%$ serat pangan tidak larut dan $2 \%$ serat pangan larut ${ }^{4}$.

\section{Hasil Ekstraksi Tepung Bentul}

Umbi Bentul yang telah menjadi tepung dilakukan proses ekstraksi. Proses ekstraksi dengan cara melarutkan tepung bentul dalam aquadest panas sehingga mempercepat proses ekstraksi. Selanjutnya ditambah dengan tawas untuk menghilangkan pengotor dan diaduk selama 1 jam agar larutan tersebut menjadi homogen. Hasil dari pengadukan tersebut kemudian dilakukan sentrifuge dengan kecepatan 3000 rpm selama 10 menit. Hal ini mengacu pada penelitian Saputri $(2013)^{4}$. Sentrifuge ini dilakukan untuk mendapatkan supernatan yang telah dipisahkan dengan endapan. Supernatan 
ditambahkan dengan etanol $96 \%$ dengan perbandingan 1:1 dan diaduk. Penambahan pelarut organik berlebih dalam supernatan berisi PLA akan mengurangi kelarutan PLA dalam air dengan cara menurunkan konstanta dielektrik medium sehingga molekul polisakarida cenderung berinteraksi dengan polisakarida lain daripada dengan air. Keadaan ini terus berlanjut sehingga dicapai titik tertentu dimana polisakarida menggumpal atau mengendap. Hasil gumpalan putih yang terapung dan mengendap dalam wadah adalah PLA. Hasil polisakarida larut air (PLA) ini kemudian dikeringkan. Hasil Polisakarida Larut Air (PLA) dari umbi bentul dapat dilihat pada tabel 2.

Tabel 2. Hasil Rendemen Polisakarida Larut Air (PLA) dari umbi bentul

\begin{tabular}{ccccc}
\hline $\begin{array}{c}\text { Sampel } \\
\mathbf{1} \text { T. } \\
\text { Bentul }\end{array}$ & $\begin{array}{c}\text { Sampel } \\
\mathbf{2} \text { T. } \\
\text { Bentul }\end{array}$ & $\begin{array}{c}\text { Ubi } \\
\text { kelapa } \\
\text { ungu* }\end{array}$ & $\begin{array}{c}\text { Ubi } \\
\text { kelapa } \\
\text { kuning * }\end{array}$ & $\begin{array}{c}\text { Gembili } \\
* *\end{array}$ \\
\hline $2,9 \%$ & $9,0 \%$ & $0,12 \%$ & $0,105 \%$ & $4,86 \%$ \\
\hline
\end{tabular}

Sumber: *Saputri, 2013; **Estiasih et al. 2012

PLA dari umbi bentul ini lebih besar dari ubi kelapa ungu yaitu $0,12 \%$, ubi kelapa kuning $0,105 \%$ dan PLA yang diekstraksi dari umbi gembili (Dioscorea hispida) yaitu 3 $5 \%$. Artinya PLA pada umbi bentul ini memiliki potensi yang bisa dikembangkan dan dicari metode ekstraksi yang tepat sehingga didapatkan PLAdengan rendemen yang maksimal.

\section{Hasil Analisa Ekstrak}

Polisakarida larut air (PLA) merupakan serat pangan larut air yang didefinisikan sebagai komponen dalam tanaman yang tidak terdegradasi secara enzimatis menjadi sub unit yang dapat diserap dilambung dan usus halus. Kadar polisakarida air larut (PLA) dari uwi ungu dan kuning menurut penelitian Apriliyanti (2013) adalah 572,20 mg/ 100 gram dan 110,90 mg/ 100 gram . Sedangkan dalam penelitian ini didapatkan hasil yang lebih kecil, adapun hasilnya bisa dilihat pada Gambar 1 .

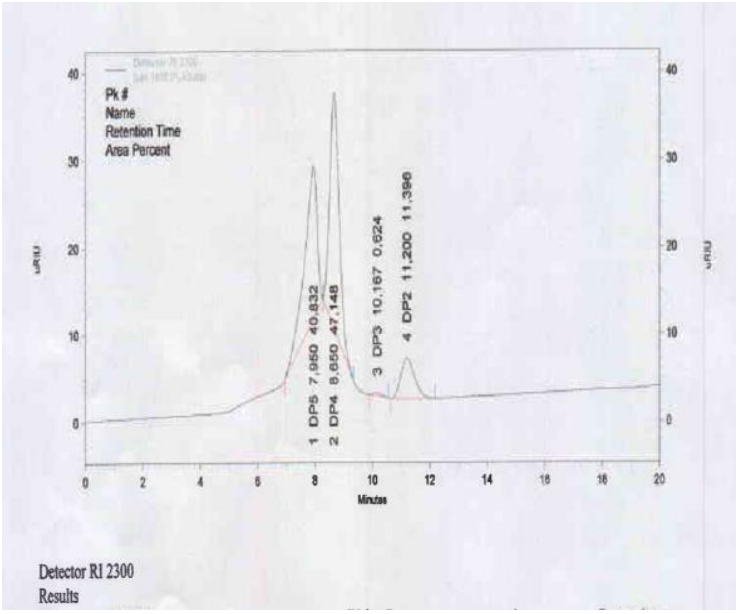

Gambar 1.Hasil Analisa Tepung Bentul dengan HPLC dengan rendemen 9,00\%

Pada gambar 1 dapat dilihat pada DP4 dan DP 5 dengan persen area DP4 47,148 dan pada DP 5 diperoleh persen area sebesar 40,832 sehingga total adalah sebesar $87,98 \%$. Sedangkan pada rendemen 2,9\% didapatkan hasil pada Gambar 2.

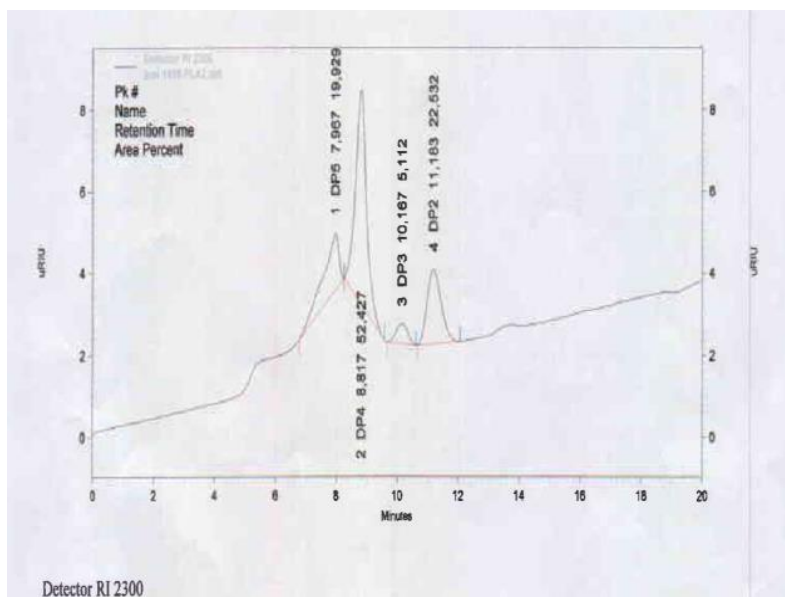

Gambar 2. Hasil Analisa Tepung Bentul dengan HPLC dengan rendemen 2,9\%

Pada hasil analisis gula terdapat hasil yang menyatakan DP1, fructose, DP2, maltose, DP3, DP4, dan DP5. DP1, DP2, DP3, DP4, dan DP5 menyatakan persen area yang merupakan Degres of Polymer. DP1 adalah monosakarida yang memiliki 1 monomer, DP2 adalah disakarida yang memiliki 2 monomer, DP3 adalah oligosakarida yang memiliki 3-10 monomer, dan DP4 serta DP5 adalah polisakarida yang memiliki lebih dari 10 monomer. 
Tabel 3. Hasil Analisa HPLC

\begin{tabular}{ccc}
\hline Rendemen & $\mathbf{9 , 0 0 \%}$ & $\mathbf{2 , 9 \%}$ \\
\hline Total DP4 dan DP5 & $87,98 \%$ & $78,23 \%$ \\
\hline
\end{tabular}

Hasil analisa menggunakan HPLC diatas dapat diketahui bahwa rendemen tepung sebesar 2,9\% didapatkan nilai total dari DP4 dan DP5 sebesar 78,23\%. Sedangkan, rendemen tepung $9 \%$ didapatkan nilai total $87,98 \%$. Pada proses ekstraksi pada penelitian ini diduga dihasilkan enzim yang dapat menghidrolisis PLA sehingga didapatkan kadar gula bebas. Molekul polisakarida yang membentuk PLA adalah hasil kondensasi dari monosakarida (pentosa dan heksosa) dan asam organik yang terbentuk dari gula-gula reduksi. Menurut Saputro, (2015) jika PLA dihidrolisis akan menghasikan bermacam macam monosakarida antara lain rhamonosa, fruktosa (metil pentosa), arabinosa, D-glukosa, D-mannosa, D-galaktosa, asam D-galakturonat atau asam D-glikoronat ${ }^{11}$. Penelitian Harijono, dkk (2012) menyebutkan bahwa hasil analisis jenis gula bebas menunjukkan bahwa PLA gembili mengandung glukosa dan manosa ${ }^{1}$.

Dalam penelitian ini tepung umbi bentul mengandung polisakarida larut air yang sifatnya dapat menyerap air dan meningkatkan viskositas. Polisakarida larut air pada konsentrasi di bawah $1 \%$ yang dicampur dengan adonan dapat menjaga stabilitas adonan yang disebabkan interaksi antara pati dan gugus hidroksil pada hidrokoloid ${ }^{12}$. Menurut Dodic, et al., (2007), polisakarida memodifikasi dan mengontrol mobilitas air dalam sistem bahan pangan, dan air mempunyai peran penting dalam mempengaruhi sifat fisik dan kimia polisakarida ${ }^{13}$. Polisakarida bersama dengan air mengendalikan banyak sifat fisiko-kimia pangan termasuk tekstur, hal ini disebabkan hidrasi air secara alami terikat dengan ikatan hidrogen pada molekul polisakarida sehingga air tersebut tidak akan membeku. Sehingga keberadaan PLA pada umbi bentul ini dapat diaplikasikan pada produk pangan.

Melihat hasil pada DP 4 dan DP 5 yang mengandung PLA maka umbi bentul dapat dijadikan suatu alternatif bagi penderita penyakit degeneratif. Hal ini sesuai peryataan
Harijono, dkk (2012) PLA yang merupakan serat pangan larut air dapat mengurangi penyakit degeneratif seperti diabetes ${ }^{1}$. Konsumsi yang memiliki serat tinggi sangat dibutuhkan penderita diabetes. Fermentasi PLA di kolon menghasilkan asam lemak rantai pendek (SCFA) yang akan akan memicu penurunan lipid dalam darah. Banyak sekali manfaat yang didapat dari PLA, sehingga perlu adanya penelitian untuk mengetahui gula penyusun yang dimiliki oleh umbi bentul sehingga akan semakin banyak manfaat yang didapat dengan mengonsumsi umbi bentul.

\section{KESIMPULAN}

Berdasarkan dari penelitian identifikasi senyawa bioaktif pada tepung umbi bentul (Colocasia esculenta (L.) Schott) didapat hasil komponen kimia pada tepung umbi bentul dengan kadar protein 3,45\%, kadar lemak 0,31\%, kadar air 6,07\%, kadar abu 2,14\%, kadar karbohidrat $88,03 \%$, dan kadar serat $2,87 \%$. Hasil kimia tersebut menunjukkan bahwa umbi bentul memiliki nilai gizi yang tinggi sehingga dapat dijadikan olahan pangan lainnya. Hasil analisa dari ekstrak tepung didapat hasil adanya bioaktif berupa polisakari dalarut air (PLA) yang ditandai dengan DP4 dan DP5 HPLC dengan total $72,35 \%$ dan $87,98 \%$. Kandungan PLA umbi bentul tersebut dapat berfungsi untuk mengatasi penyakit degeneratif sehingga umbi bentul ini dapat dijadikan sebagai pangan fungsional.

\section{ACKNOWLEDGEMENT}

Penulis mengucapkan terima kasih atas dukungan dan masukan dari LPPM Akademi Analis Farmasi Dan Makanan Putra Indonesia Malang, serta PT.SASA INTI Gending Probolinggo.

\section{REFERENSI}

1. Harijono, Estiasih, T., Sunarharum, W. B., \& Suwita, I. K. 2012. Efek Hipoglikemik Polisakarida Larut Air Gembili (Dioscorea esculenta) yang Diekstrak dengan Berbagai Metode. Jurnal Teknologi dan Industri Pangan. 
2. Prabowo, A. Y., Estiasih, T., \& Purwantiningrum, I. 2014. Umbi Gembili (Dioscorea esculenta L.) sebagai Bahan Pangan Mengandung Senyawa Bioaktif : Kajian Pustaka. Jurnal Pangan dan Agroindustri , 129-135.

3. Herlina, \& Lindriati, T. 2014. Produksi Polisakarida Larut Air dari Biji Buah Durian (Durio zibenthinus Murr.) dan Aplikasinya untuk Pangan Fungsional sebagai Hipolidemik.

4. Saputri, D. S. 2013. Pengaruh Perendaman dan Blansing Terhadap Kadar Senyawa Bioaktif dan Karakteristik Tepung Ubi Kelapa (Dioscorea alata) Jenis Kuning dan Ungu. Tesis. Skripsi Jurusan Ilmu dan Teknologi Pangan Fakultas Teknologi Pertanian Universitas Brawijaya Malang.

5. Estiasih et al. 2012. Hypoglycemic Activity of Water Soluble Polysaccharides of Yam (Dioscorea hispida Dents) Prepared by Aqueous, Papain, and Tempeh Inoculum Assisted Extractions. World Academy of Science, Engineering and Technology, Vol: 6 2012-10-27.

6. Enrique Sarano M, Avierions JF, MessikaZeitoun D, et al. Quantitative determinants of the outcome of asymptomatic mitral regurgitation. New England Journal of Medicine. 2005:352:875-883
7. Ambarsari, I., Sarjana, \& Choliq, A. 2009. Rekomendasi dalam Penetepan Standar Mutu tepung Ubi Jalar. Jurnal Standarisasi, vol.11(3): 212-219.

8. Richana, N., \& Sunarti, T. C. 2004. Karakterisasi Sifat Fisikokimia Tepung Umbi dan Tepung Pati dari Umbi Ganyong, Suweg, Ubi Kelapa, dan Gembili. Jurnal Pascapanen , 29-37.

9. Badan Standarisasi Nasional. 2009. Tepung Terigu Sebagai Bahan Makanan. SNI 3751-2009.

10. Nurcahya, H. 2013. Budidaya dan Cara Olah Talas untuk Makanan dan Obat. Yogyakarta : Pustaka Baru Press

11. Saputro, P. S., \& Estiasih, T. 2015. Pengaruh Polisakarida Larut Air (PLA) dan Serat Pangan Umbi-umbian Terhadap Glukosa Darah : Kajian Pustaka. Jurnal Pangan dan Agroindustri , 756-762.

12. Ho, L., \& N, A. 2013. Dough Mixing and Thermal Properties Including The Pasting Profiles of Composite Flour Blends with Added Hydrocolloids. Internasional Food Research Journal , 20(2): 911-917.

13. Dodic, J. D. Pejin, S. Dodic, S. Pupon, J. Mastilovic, J.P. Rajic and S. Zivanovic. 2007. Effects of Hydrophillic Hydrocolloids or Dough and Bread Performance of Samples Made From Frozen Dought. J. Food Sci, 72 :235-244 